Proc. Estonian Acad. Sci. Biol. Ecol., 2003, 52, 1, 3-16

\title{
A comparison between 1928 and 2000 indicates major changes in the macrozoobenthos species composition and abundance on the SW coast of Finland (Baltic Sea)
}

\author{
Ari O. Laine ${ }^{\mathrm{a}, \mathrm{b} *}$, Kaisa Luodekari ${ }^{\mathrm{c}}$, Minna Poikonen ${ }^{\mathrm{c}}$, \\ and Markku Viitasalo \\ a Finnish Environment Institute, P.O.Box 140, FIN-00251 Helsinki, Finland \\ b Finnish Institute of Marine Research, P.O.Box 33, FIN-00931 Helsinki, Finland \\ ${ }^{c}$ University of Helsinki, Department of Hydrobiology, P.O.Box 65, FIN-00014 Helsingin yliopisto, \\ Finland
}

Received 8 July 2002, in revised form 20 November 2002

\begin{abstract}
In 1928, Sven G. Segerstråle made detailed analyses of benthic communities in the Tvärminne region (SW coast of Finland). In addition to traditional presentation, he included illustrative photographs where the collected macroinvertebrates were laid on black background, in natural density, and reproduced in their natural size. This approach was replicated in the present study. The photographs highlight changes that have taken place during the past century in the benthic communities. In the deeper area there has been a change from an amphipod (Monoporeia affinis) dominated community to one dominated by the Baltic clam Macoma baltica. In the shallower study area the diverse Corophium volutator-M. baltica-chironomid community has been replaced by a community dominated by Macoma and a North American invader, the polychaete Marenzelleria viridis. Furthermore, the density of macroinvertebrates has declined considerably. The causes for these changes remain unclear, but are most likely connected to eutrophication related factors in the coastal ecosystem and concurrent interspecific interactions.
\end{abstract}

Key words: macrozoobenthos, long-term change, Baltic Sea.

\section{INTRODUCTION}

Soft bottom macrozoobenthos communities in the northern Baltic Sea have typically a low diversity, resulting often from the high dominance of only a few species adapted to the brackish water conditions (e.g. Andersin et al., 1977;

* Corresponding author, ${ }^{\mathrm{b}}$ present address; ari.laine@ fimr.fi 
Elmgren, 1978). Both long-term trends and sudden changes have been reported in the communities, illustrating high variability in abundance and changes in the species composition (Segerstråle, 1960a; Karjala \& Lassig, 1985; Andersin \& Sandler, 1991; Laine et al., 1997; Hänninen \& Vuorinen, 2001). The main abiotic factors causing both spatial and temporal variability in the communities include salinity and oxygen conditions (Andersin et al., 1977; Bonsdorff et al., 1996; Laine et al., 1997; Bonsdorff \& Pearson, 1999) but also changes caused by food availability and eutrophication have been suggested (Cederwall \& Elmgren, 1980; Bonsdorff et al., 1997; Lehtonen \& Andersin, 1998). In addition, complex intra- and interspecific competition and predation effects have been demonstrated (Uitto \& Sarvala, 1990; Bonsdorff \& Blomqvist, 1993; Ejdung \& Elmgren, 1998) and settlement of nonindigenous species has added new components to the species poor benthic communities (Stigzelius et al., 1997), which may affect the original species (e.g. Kotta et al., 2001).

In the 1920s Segerstråle (1933a, 1933b) started extensive quantitative macrofauna studies on the SW coast of Finland, which now serve as a valuable reference for the long-term change of the communities. The studies in the Tvärminne area were continued sporadically during the following decades (Segerstråle, 1960b) and since 1964 two of the sampling stations established by Segerstråle have been monitored annually (Karjala \& Lassig, 1985). Macrofauna communities have notably changed in the Finnish coastal waters during the last decades. A common feature seems to be a deterioration of the communities, especially a decline of the formerly abundant amphipod populations (Mattila, 1993; Varmo, 1994; Valkama \& Anttila-Huhtinen, 2000; Kangas et al., 2001). However, many of these studies have been made in areas affected by direct pollution (municipal or industrial) and reference to an unaffected state is meager. The Tvärminne area has been considered as a relatively unaffected area and it can be suggested that the 1920s represent a period with only minor anthropogenic effects.

In the studies conducted in 1928, Segerstråle (1933b) presented detailed descriptions of benthic communities in the Tvärminne region. He included illustrative photographs where the collected macroinvertebrates were reproduced in their natural size and density. In the present study we replicated this approach by taking benthos samples from the same locations and photographing the specimens in the same way as Segerstråle did. The aim of this study is to demonstrate differences in the macrozoobenthos communities over a period of more than 70 years.

\section{MATERIAL AND METHODS}

The study area is located in SW Finland, in the archipelago area of the western Gulf of Finland. Two sampling sites (Fig. 1) studied in September-October 1928 (Segerstråle, 1933a) were revisited in July 2000.

Station I is located in shallow and sheltered Krogarviken Bay just outside the Tvärminne Zoological Station. Bottom samples were taken from $3 \mathrm{~m}$ depth. 


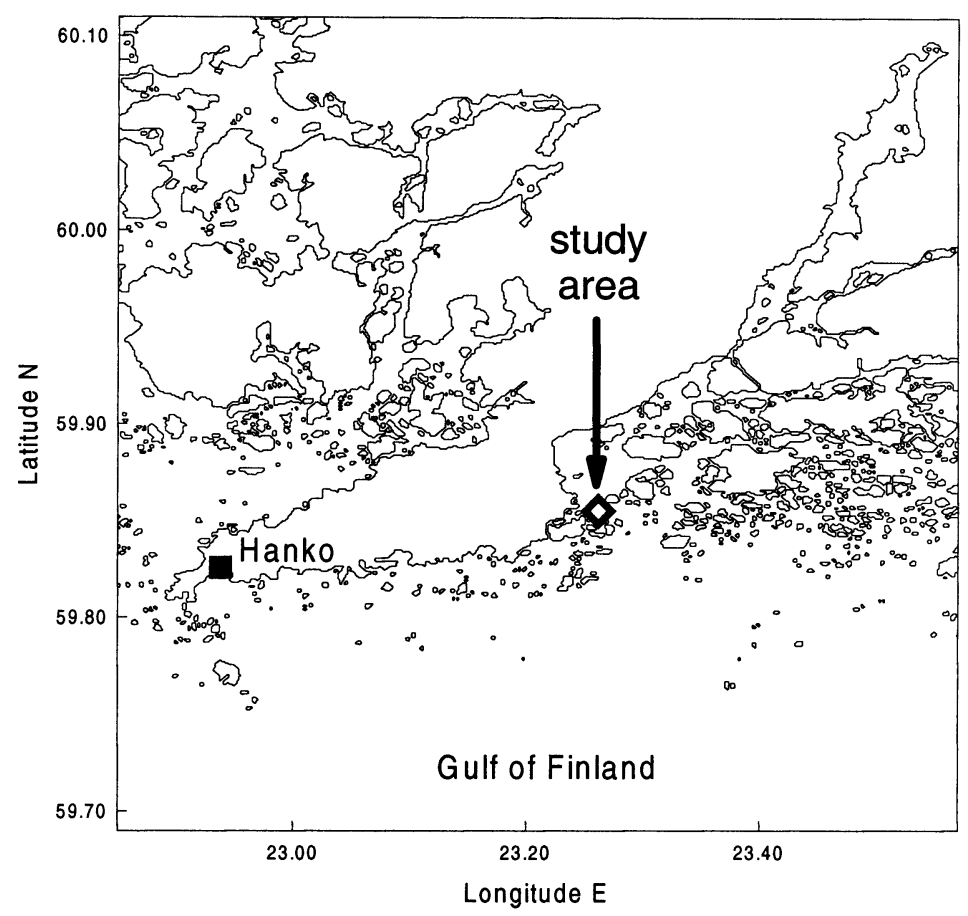

Fig. 1. Location of the study area on the SW coast of Finland, Baltic Sea.

Samples consisted of soft mud rich in organic debris. Segerstråle (1933a) described the bottom as dark gray mud and some sand, with relatively heterogeneous and coarse detritus, thus corresponding to the present samples. Station XLIV is located in the more open Storfjärden basin, with a depth of $35 \mathrm{~m}$. According to Segerstråle (1933a) the bottom consists of soft, blackish mud with relatively fine and homogeneous detritus. This is in line with the sampling in 2000.

In 1928 an Ekman-Birge grab was used, with a sampling area of $0.023 \mathrm{~m}^{2}$. At station I 30 samples were taken, thus covering a total area of $0.70 \mathrm{~m}^{2}$. At station XLIV 25 samples were taken, corresponding to $0.59 \mathrm{~m}^{2}$. The samples were washed with seawater on a 1-mm sieve, preserved, and afterwards identified and counted. Specimens were laid on black cardboard (area $0.018 \mathrm{~m}^{2}$ ) at a natural density and photographed (Segerstråle, 1933a, 1933b).

In 2000 samples were taken with a Van Veen grab, which samples an area of $0.1052 \mathrm{~m}^{2}$. Only one sample was taken at both stations. The samples were washed with seawater on a 1-mm sieve and counted and identified under a dissecting microscope. As in 1928, specimens were laid on black background (area $0.018 \mathrm{~m}^{2}$ ) at a density representing the natural situation on the bottom and photographed with a digital camera. Rare species that occurred at a density less than one specimen on the photographed area are represented in the inserted smaller pictures. 


\section{RESULTS}

At the 3-m station I a change from a Corophium volutator-Macoma balticaChironomidae community to one dominated by M. baltica had occurred. In 1928, 14 species were recorded compared to 8 species in 2000 (Table 1, Figs. 2 and 3). There also was a decline in total abundance from 4676 ind. $\mathrm{m}^{-2}$ in 1928 to 345 ind. $\mathrm{m}^{-2}$ in 2000 . As many as 11 species, including all crustacean species, had disappeared and only 3 species were found that occurred both in 1928 and 2000. One of the four new species in 2000 was the North American invader Marenzelleria viridis (Polychaeta).

Table 1. Macrozoobenthos density (ind. $\mathrm{m}^{-2}$ ) in 1928 (Segerstråle, 1933b) and in 2000 at stations I and XLIV. The numbers in bold represent the most abundant species shown in the main pictures in Figs. 3 and 4

\begin{tabular}{|c|c|c|c|c|}
\hline \multirow[t]{2}{*}{ Species } & \multicolumn{2}{|c|}{ Station I } & \multicolumn{2}{|c|}{ Station XLIV } \\
\hline & 30.09 .1928 & 03.07 .2000 & 03.10 .1928 & 03.07 .2000 \\
\hline \multicolumn{5}{|l|}{ Nemertinea } \\
\hline Prostoma obscurum & 1 & & 2 & \\
\hline \multicolumn{5}{|l|}{ Priapulida } \\
\hline Halicryptus spinulosus & & & 75 & \\
\hline Oligochaeta & & 10 & & \\
\hline Tubifex tubifex & 67 & & & \\
\hline \multicolumn{5}{|l|}{ Polychaeta } \\
\hline Nereis diversicolor & & 10 & & \\
\hline Harmothoe sarsi & & & 145 & 19 \\
\hline Marenzelleria viridis & & 95 & & 19 \\
\hline \multicolumn{5}{|l|}{ Crustacea } \\
\hline Asellus aquaticus & 3 & & & \\
\hline Saduria entomon & 1 & & 14 & 200 \\
\hline Corophium volutator & 2433 & & & \\
\hline Gammarus locusta & 67 & & & \\
\hline Monoporeia affinis & 46 & & 7006 & 57 \\
\hline Pontoporeia femorata & & & 9 & \\
\hline \multicolumn{5}{|l|}{ Gastropoda } \\
\hline Theodoxus fluviatilis & 4 & 10 & & \\
\hline Bithynia tentaculata & 3 & & & \\
\hline Potamopyrgus jenkinsi & & 10 & & \\
\hline Hydrobia sp. & & 10 & & \\
\hline \multicolumn{5}{|l|}{ Bivalvia } \\
\hline Cardium edule & 14 & 10 & & \\
\hline Macoma baltica & 1078 & 190 & 353 & 990 \\
\hline \multicolumn{5}{|l|}{ Insecta } \\
\hline Chironomidae & 942 & & & \\
\hline Trichoptera & 16 & & & \\
\hline Sialis lutaria & 1 & & & \\
\hline Total ind. $\mathrm{m}^{-2}$ & 4676 & 345 & 7604 & 1285 \\
\hline No. of taxa & 14 & 8 & 7 & 5 \\
\hline
\end{tabular}




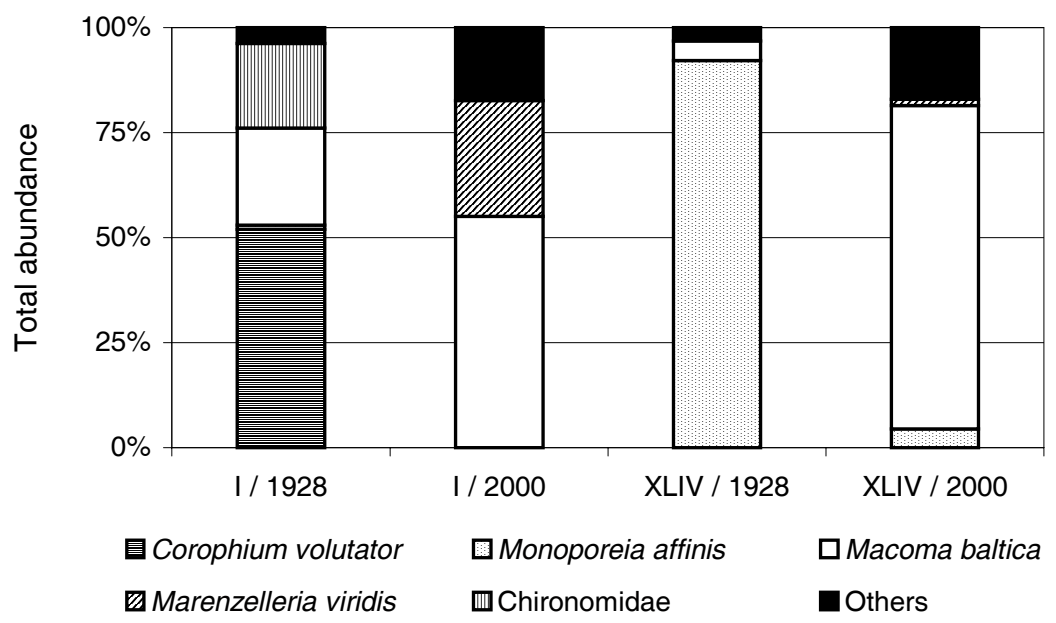

Fig. 2. A comparison of the community structure at stations I and XLIV in 1928 and 2000.

At the 35-m station XLIV the earlier amphipod Monoporeia (Pontoporeia) affinis dominated community had changed to a Macoma baltica dominated assemblage (Table 1, Figs. 2 and 4). Concurrently, the total abundance declined from 7600 ind. $\mathrm{m}^{-2}$ in 1928 to less than 1300 ind. $\mathrm{m}^{-2}$ in 2000 . The most drastic change was the decline of $M$. affinis, contributing to more than $90 \%$ of the total abundance in the late 1920s, compared to less than 5\% in 2000. M. baltica had increased in abundance, and made up more than $75 \%$ of the total abundance in 2000. Compared to the shallower site, the difference in the species composition seems to be smaller ( 7 and 5 species in 1928 and 2000, respectively, with 4 common species).

\section{DISCUSSION AND CONCLUSIONS}

\section{Changes in the macrofauna community}

The results showed distinct differences between the two sampling occasions, a 6- to 14-fold decline in the total abundance and changes in the species composition. In 1928 the communities were dominated by deposit-feeding amphipods, Corophium volutator (station I) and Monoporeia affinis (station XLIV), while in 2000 Macoma baltica clearly dominated in abundance at both sites. This has resulted in a greater similarity in the community structure between the two sites in 2000. Despite the smaller total abundance today, the biomass of the community at the deeper site is obviously much higher due to the presence of large Macoma.

However, caution is needed when drawing conclusions on changes that have taken place between the two samplings. In this case we know that the abundant 
(a)
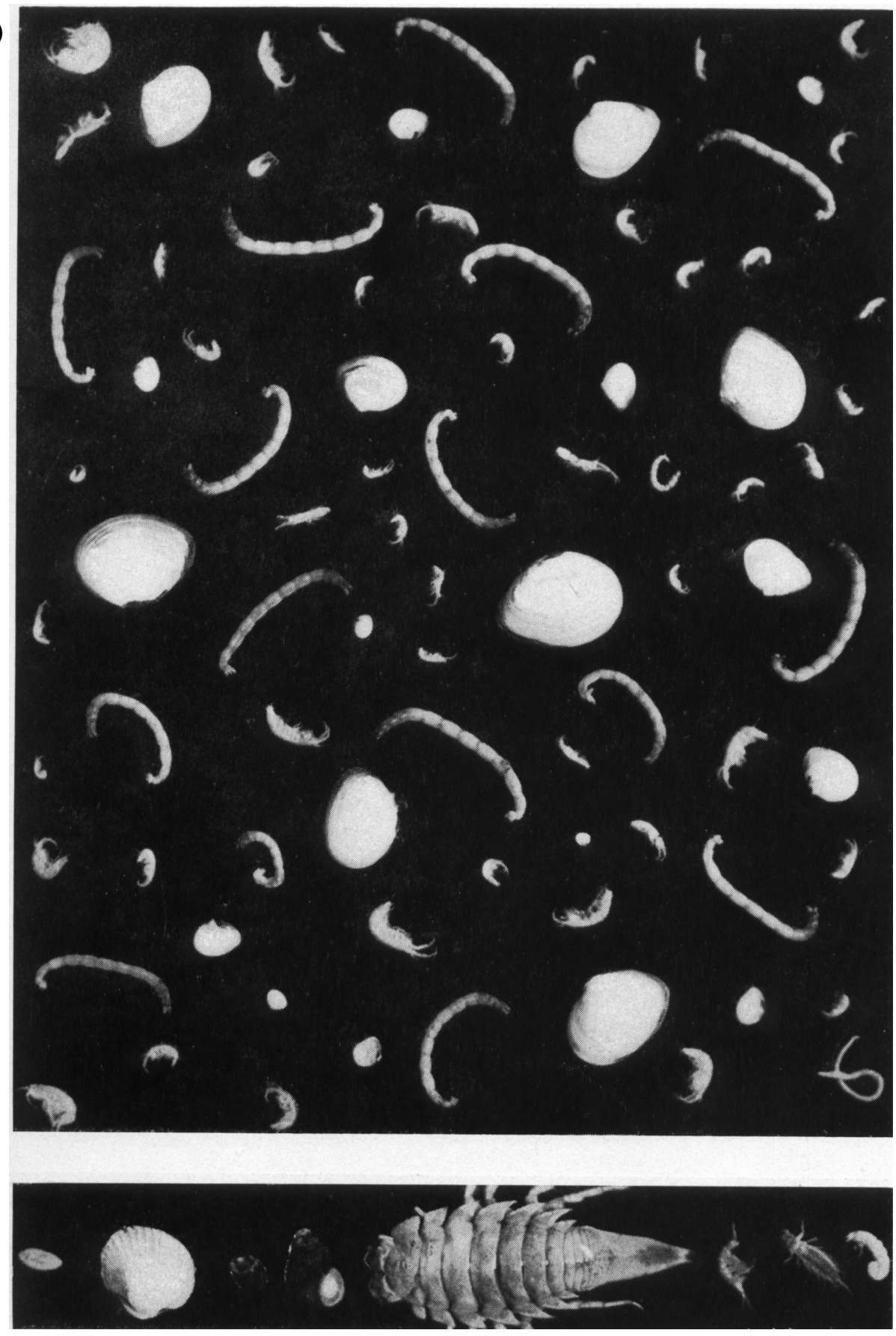

Fig. 3. Macrozoobenthos community at station I $(3 \mathrm{~m})$ photographed in its natural density in (a) 1928 (Segerstråle, 1933b) and (b) 2000. The area of the main picture is $0.018 \mathrm{~m}^{2}$. The inserted smaller pictures below show rare species, with a density less than the depicted area $\left(<56\right.$ ind. $\left.\mathrm{m}^{-2}\right)$ See Table 1 for the species list. 
(b)
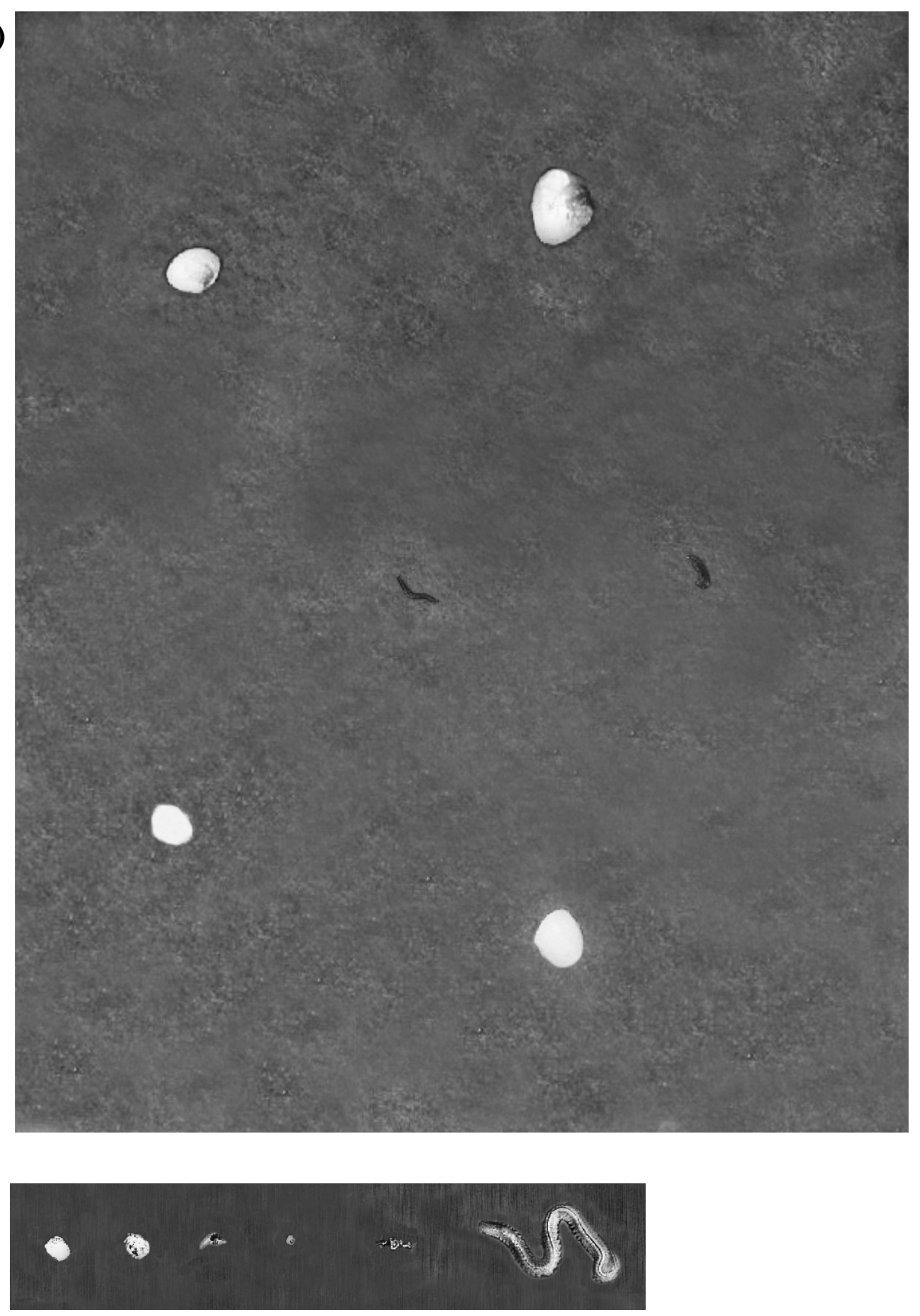

Fig. 3. Continued. 
(a)
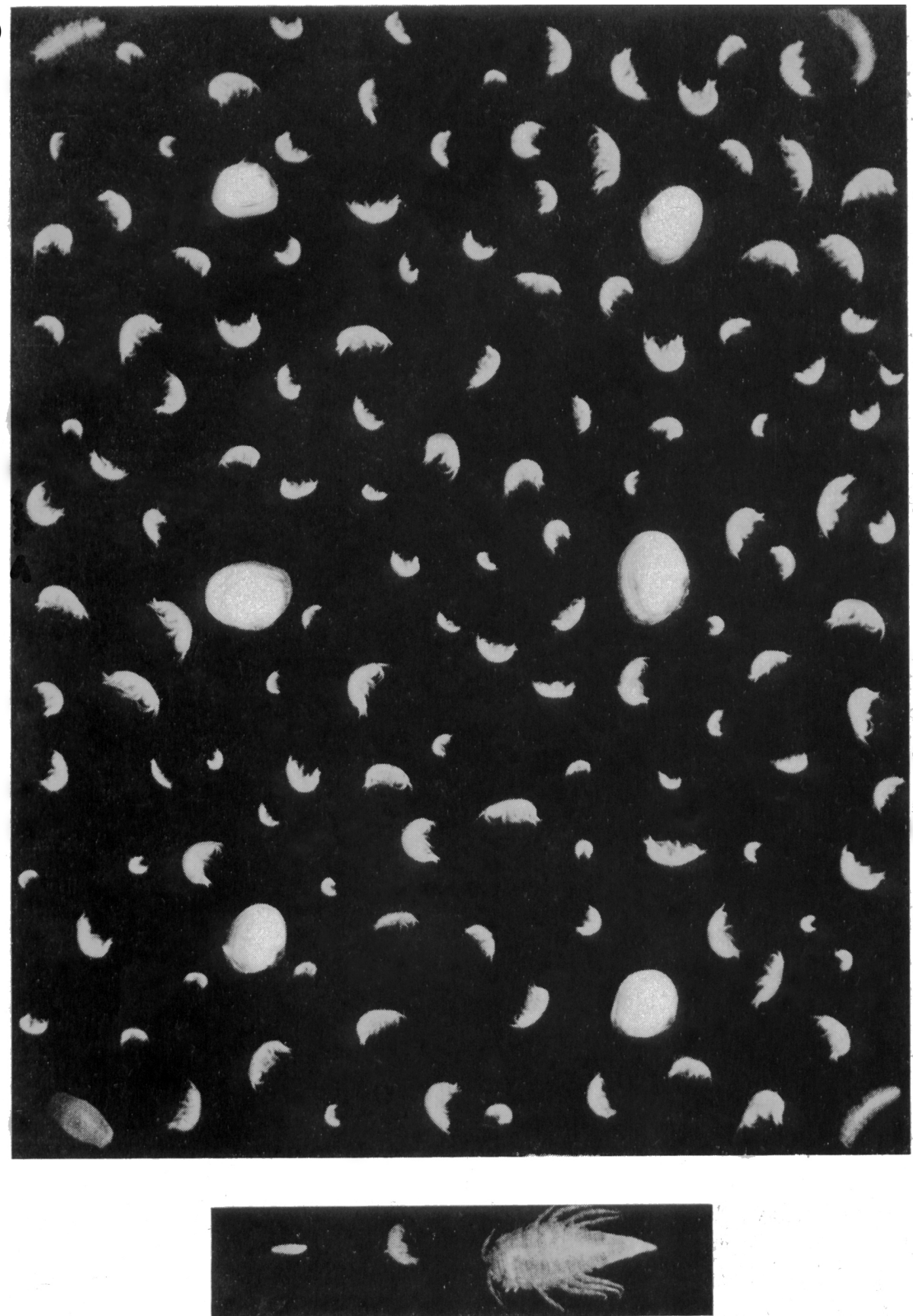

Fig. 4. Macrozoobenthos community at station XLIV $(35 \mathrm{~m})$ photographed in its natural density in (a) 1928 (Segerstråle, 1933b) and (b) 2000. The area of the main picture is $0.018 \mathrm{~m}^{2}$. The inserted smaller pictures below show rare species, with a density less than the depicted area $\left(<56\right.$ ind. $\left.\mathrm{m}^{-2}\right)$. See Table 1 for the species list. 

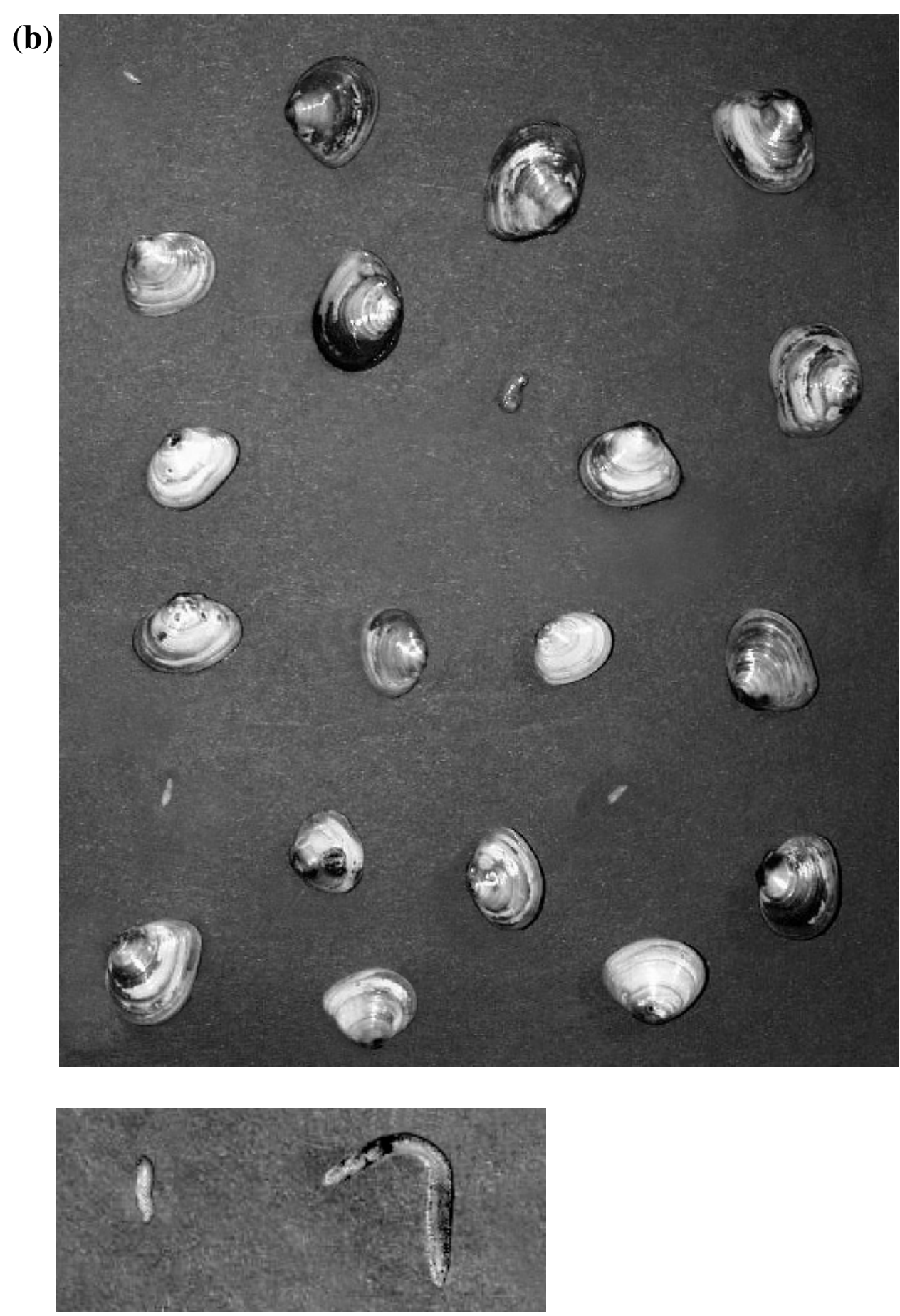

Fig. 4. Continued. 
Chironomidae, Corophium volutator, and Monoporeia affinis populations recorded in 1928 decreased dramatically in the following years (Segerstråle, 1960a), thus not necessarily representing a lasting state of the communities. In the case of $M$. affinis, a true long-term decline has been observed in the study area since the high-abundance period in the 1960s and 1970s, accompanied by a distinct increase of M. baltica. This species was abundant also in the $1920 \mathrm{~s}-30 \mathrm{~s}$ but occurred in low abundance for decades until the recent increase in the 1990s (Segerstråle, 1960b; Karjala \& Lassig, 1985; Kangas et al., 2001). For C. volutator a decline since the 1970s has been reported on shallow sandy bottoms (Boström et al., 2002). The truly new species found at both sites, the North American polychaete Marenzelleria viridis, was introduced to the Baltic Sea in 1985 and was found for the first time in the Tvärminne area in 1990 (Stigzelius et al., 1997). Since then the species seems to have established permanent populations and is found commonly in coastal waters (e.g. Norha, 2001; Perus et al., 2001).

We recognize that our study only shows two snapshots in time. In the light of other studies we, however, consider these snapshots representative ones, correctly illustrating the change in benthic communities that has taken place in the study area.

\section{Could methodological differences explain the observed differences?}

Methodological differences may affect results (Ankar et al., 1979; Elliott \& Drake, 1981) but are unlikely to explain the observed differences in the community structure. The main factors of concern in this study are the difference in the grab type and sample size. The Van Veen grab is much heavier and obviously penetrates deeper in the sediment than the light Ekman corer used by Segerstråle (1933a, 1933b). Therefore, the number of deep burrowing animals could be underestimated in the 1928 material. In 1928 the total area sampled was smaller; however, due to the high number of samples per station, rare species are obviously better represented in the earlier material and can partly explain the higher number of observed species. However, both methods are obviously adequate for studying major differences between the samplings. The sieve size and the difference in the sampling time may affect the number of small amphipods. However, according to Uitto \& Sarvala (1991) the 0+ age group of Monoporeia reaches a length of $3 \mathrm{~mm}$ by July and thus these factors are unlikely to explain the considerable difference in the abundance between the two sampling occasions. In general, the present results for the deeper station XLIV agree well with the monitoring data for the area (Kangas et al., 2001).

\section{Changes in the environment and interspecific interactions}

One of the main environmental factors affecting species distribution and

community structure in the Baltic Sea is salinity (e.g. Segerstråle, 1965; Bonsdorff $\&$ Pearson, 1999). In the 1930s a salinity minimum prevailed in the northern 
Baltic and a maximum was experienced in the late 1970s. Since then salinity has been decreasing almost continuously, followed by a small increase again in the late 1990s (Alenius \& Haapala, 1992; Alenius et al., 1998). In the study area salinity has declined by 1 psu since the 1970s when near-bottom values exceeding 7 psu were observed (Finnish Institute of Marine Research, unpublished data). Thus both sampling occasions represent low-salinity periods and are comparable in this respect. However, low surface temperatures were recorded in the $1920 \mathrm{~s}$ (Alenius \& Haapala, 1992), which could have contributed to the occurrence of the cold-stenothermal M. affinis in the shallow waters (Segerstråle, 1978).

Eutrophication of the Baltic Sea has been documented since the 1950s (Larsson et al., 1985; Nehring \& Matthäus, 1991) and for example deposition of organic matter has been estimated to have almost doubled in the northern Baltic proper during the last decade (Jonsson \& Carman, 1994). In the Gulf of Finland an intensification of the spring bloom has been observed (Grönlund \& Leppänen, 1992) and an increase in the nutrient concentrations was observed again in the late 1990s (Perttilä et al., 1995; Kuparinen \& Tuominen, 2001; Pitkänen et al., 2001a). Stratification related oxygen deficiency has been mainly considered a problem of the deeper subhalocline areas and some local isolated basins in the archipelago (Bagge \& Voipio, 1967; Andersin \& Sandler, 1991). Recently there has been increasing concern about the deterioration of bottoms in the more coastal waters as well, manifested as increasing loading of organic matter, more frequent hypoxia, and consequently increased internal loading (Rosenberg \& Diaz, 1993; Bonsdorff et al., 1997; Pitkänen et al., 2001a, 2001b). In the study area, however, no direct evidence exists on changes in the oxygen conditions, this is also supported by the presence of permanent infauna. On the other hand, the decline of $M$. affinis and the increase of M. baltica are in agreement with the species response to eutrophication, as studied by Leppäkoski (1975). It has been suggested that $M$. baltica populations thrive in areas where disturbance generated by M. affinis is minimal, thus allowing successful recruitment of $M$. baltica larvae (Segerstråle, 1973; Ejdung \& Elmgren, 1998). The scarcity of the amphipods could explain the abundance of Macoma in the present study.

In conclusion, a considerable decline in the abundance and a change from an amphipod to a bivalve dominated community were observed when comparing the present results to previous findings. The reasons underlying these changes remain unresolved, but as the salinity level during both periods was similar, we suggest that they are most likely connected to eutrophication related factors in the coastal ecosystem and concurrent interspecific interactions.

\section{ACKNOWLEDGEMENTS}

The Helsinki University field course on the Ecology of the Baltic Sea 2000 is acknowledged for careful sampling and treatment of the material, and the Tvärminne Zoological Station for providing the facilities. Mr. Riku Lumiaro 
helped by editing the digital images. The photographs by S. G. Segerstråle were reproduced with the kind permission of the Finnish Science Association (Suomen Tiedeseura). This study was financially supported by Maj and Tor Nessling Foundation.

\section{REFERENCES}

Andersin, A.-B. \& Sandler, H. 1991. Macrobenthic fauna and oxygen deficiency in the Gulf of Finland. Memo. Soc. Fauna Flora Fenn., 67, 3-10.

Andersin, A.-B., Lassig, J. \& Sandler, H. 1977. Community structure of soft-bottom macrofauna in different parts of the Baltic. In Biology of Benthic Organisms (Keegan, B. F., Ceidigh, P. O. \& Boaden, P. J. S., eds.), pp. 8-20. Pergamon Press, New York.

Alenius, P. \& Haapala, J. 1992. Hydrographic variability in the Northern Baltic in the twentieth century. ICES Mar. Sci. Symp., 195, 478-485.

Alenius, P., Myrberg, K. \& Nekrasov, A. 1998. The physical oceanography of the Gulf of Finland: a review. Bor. Env. Res., 3, 97-125.

Ankar, S., Andersin, A.-B., Lassig, J., Norling, L. \& Sandler, H. 1979. Methods for studying benthic macrofauna. An intercalibration between two laboratories in the Baltic Sea. Finn. Mar. Res., 246, 147-160.

Bagge, P. \& Voipio, A. 1967. Disturbed bottom and hydrographic conditions in some coastal areas of Finland. I. Loviisa. Merentutkimuslaitoksen Julk./Havsforskningsinstitutets Skr., 223, 3-12.

Bonsdorff, E. \& Blomqvist, E. M. 1993. Biotic couplings on shallow water soft-bottoms - examples from the northern Baltic Sea. Oceanogr. Mar. Biol. Ann. Rev., 31, 153-176.

Bonsdorff, E. \& Pearson, T. H. 1999. Variation in sublittoral macrozoobenthos of the Baltic Sea along environmental gradients: a functional-group approach. Austr. J. Ecol., 24, 312-326.

Bonsdorff, E., Diaz, R. J., Rosenberg, R., Norkko, A. \& Cutter, G. R., Jr. 1996. Characterization of soft-bottom benthic habitats of the Åland Islands, northern Baltic Sea. Mar. Ecol. Prog. Ser., 142, 235-245.

Bonsdorff, E., Blomqvist, E. M., Mattila, J. \& Norkko, A. 1997. Coastal eutrophication: causes, consequences and perspectives in the archipelago areas of the northern Baltic Sea. Est. Coast. Shelf Sci., 44, 63-72.

Boström, C., Bonsdorff, E., Kangas, P. \& Norkko, A. 2002. Long-term changes of a brackish-water eelgrass (Zostera marina L.) community indicate effects of coastal eutrophication. Est. Coast. Shelf Sci., 55, 795-804.

Cederwall, H. \& Elmgren, R. 1980. Biomass increase of benthic macrofauna demonstrates eutrophication of the Baltic Sea. Ophelia, Suppl., 1, 287-304.

Ejdung, G. \& Elmgren, R. 1998. Predation on newly settled bivalves by deposit feeding amphipods: a Baltic Sea case study. Mar. Ecol. Prog. Ser., 168, 87-94.

Elliott, J. M. \& Drake, C. M. 1981. A comparative study of seven grabs used for samplig benthic macroinvertebrates in rivers. Freshwater Biol., 11, 99-120.

Elmgren, R. 1978. Structure and dynamics of Baltic benthos communities, with particular reference to the relationship between macro- and meiofauna. Kieler Meeresforsch., Sonderh., 4, 1-22.

Grönlund, L. \& Leppänen, J.-M. 1992. Variability in the nutrient reserves and pelagic productivity in the western Gulf of Finland. ICES Mar. Sci. Symp., 195, 499-506.

Hänninen., J. \& Vuorinen, I. 2001. Macrozoobenthos structure in relation to environmental changes in the Archipelago Sea, northern Baltic Sea. Boreal Env. Res., 6, 93-105.

Jonsson, P. \& Carman, R. 1994. Changes in the deposition of organic matter and nutrients in the Baltic Sea during the twentieth century. Mar. Poll. Bull., 28, 417-426.

Kangas, P., Byholm, L. \& Stigzelius, J. 2001. Changes in zoobenthos communities. In The State of Finnish Coastal Waters in the 1990s (Kauppila, P. \& Bäck, S., eds.). Finn. Environ., 472, 79-88. 
Karjala, L. \& Lassig, J. 1985. Studies on benthic macrofauna in the Tvärminne area, Gulf of Finland, 1964-1967 and 1973-1976. Hydrobiol. Res., XV, 169-181.

Kotta, J., Orav, H. \& Sandberg-Kilpi, E. 2001. Ecological consequences of the introduction of the polychaete Marenzelleria cf. viridis into a shallow-water biotope of the northern Baltic Sea. J. Sea Res., 46, 273-280.

Kuparinen, J. \& Tuominen, L. 2001. Eutrophication and self-purification: counteractions forced by large-scale cycles and hydrodynamic processes. Ambio, 30, 190-194.

Laine, A. O., Sandler, H., Andersin, A.-B. \& Stigzelius, J. 1997. Long-term changes of macrozoobenthos in the Eastern Gotland Basin and the Gulf of Finland (Baltic Sea) in relation to the hydrographical regime. J. Sea Res., 38, 135-159.

Larsson, U., Elmgren, R. \& Wulff, F. 1985. Eutrophication and the Baltic Sea: causes and consequences. Ambio, 14, 9-14.

Lehtonen, K. K. \& Andersin, A.-B. 1998. Population dynamics, response to sedimentation and role in benthic metabolism of the amphipod Monoporeia affinis in an open-sea area of the northern Baltic Sea. Mar. Ecol. Prog. Ser., 168, 71-85.

Leppäkoski, E. 1975. Assessment of the degree of pollution on the basis of macrozoobenthos in marine and brackish-water environments. Acta Acad. Abo., Ser. B, 35(2), 1-90.

Mattila, J. 1993. Long-term changes in the bottom fauna along the Finnish coast of the southern Bothnian Sea. Aqua Fenn., 23, 143-152.

Nehring, D. \& Matthäus, W. 1991. Current trends in hydrographic and chemical parameters and eutrophication in the Baltic Sea. Int. Rev. Hydrobiol., 76, 297-316.

Norha, T. 2001. Helsingin ja Espoon merialueen pohjaeläimistö vuonna 2000. In Helsingin ja Espoon merialueiden velvoitetarkkailu vuonna 2000 (Pesonen, L., ed.). Helsingin kaupungin ympäristökeskuksen monisteita, 3, 65-88.

Perttilä, M., Niemistö, L. \& Mäkelä, K. 1995. Distribution, development and total amounts of nutrients in the Gulf of Finland. Est. Coast. Shelf Sci., 41, 345-360.

Perus, J., Liljekvist, J. \& Bonsdorff, E. 2001. Långtidsstudie av bottenfaunans utveckling i den åländska skärgården - en jämförelse mellan åren 1973, 1989 och 2000. Forskn. Rapp. Husö biol. stat., 103, 1-58.

Pitkänen, H., Lehtoranta, J. \& Räike, A. 2001a. Internal nutrient fluxes counteract decreases in external load: the case of the estuarial eastern Gulf of Finland, Baltic Sea. Ambio, 30, 195201.

Pitkänen, H., Kauppila, P. \& Laine, Y. 2001b. Hydrography and oxygen conditions. In The State of Finnish Coastal Waters in the 1990s (Kauppila, P. \& Bäck, S., eds.). Finn. Environ., 472, 30-36.

Rosenberg, R. \& Diaz, R. J. 1993. Sulfur bacteria (Beggiatoa spp.) mats indicate hypoxic conditions in the inner Stockholm archipelago. Ambio, 22, 32-36.

Segerstråle, S. G. 1933a. Studien über die Bodentierwelt in süd-finländischen Küstengewässern. I. Untersuchungsgebiete, Methodik und Material. Commentat. Biol. Soc. Sci. Fenn., IV(8), $1-63$.

Segerstråle, S. G. 1933b. Studien über die Bodentierwelt in süd-finländischen Küstengewässern. II. Übersicht über die Bodentierwelt, mit besonderer Berücksichtigung der Produktionverhältnisse. Commentat. Biol. Soc. Sci. Fenn., IV(9), 1-79.

Segerstråle, S. G. 1960a. Fluctuations in the abundance of benthic animals in the Baltic area. Commentat. Biol. Soc. Sci. Fenn., XXIII(9), 1-19.

Segerstråle, S. G. 1960b. Investigations on Baltic populations of the bivalve Macoma balthica (L.). Part 1. Introduction. Studies on recruitment and its relation to depth in Finnish coastal waters during the period 1922-1959. Age and growth. Commentat. Biol. Soc. Sci. Fenn., XXIII(2), 1-72.

Segerstråle, S. G. 1965. On the salinity conditions off the south coast of Finland since 1950, with comments on some remarkable hydrographical and biological phenomena in the Baltic area during this period. Commentat. Biol. Soc. Sci. Fenn., 28(7), 1-28. 
Segerstråle, S. G. 1973. Results of bottom fauna sampling in certain localities in the Tvärminne area (inner Baltic), with special reference to the so-called Macoma-Pontoporeia theory. Commentat. Biol. Soc. Sci. Fenn., 67, 1-12.

Segerstråle, S. G. 1978. Upper limits of the depth range and temperature tolerance of the Baltic Pontoporeia affinis (Crustacea, Amphipoda). Ann. Zool. Fenn., 15, 200-201.

Stigzelius, J., Laine, A., Rissanen, J., Andersin, A.-B. \& Ilus, E. 1997. The introduction of Marenzelleria viridis (Polychaeta, Spionidae) into the Gulf of Finland and the Gulf of Bothnia (northern Baltic Sea). Ann. Zool. Fenn., 34, 205-212.

Uitto, A. \& Sarvala, J. 1990. Perspectives on the ecological factors regulating Pontoporeia populations in the northern Baltic Sea. Ann. Zool. Fenn., 27, 297-301.

Uitto, A. \& Sarvala, J. 1991. Seasonal growth of the benthic amphipods Pontoporeia affinis and P. femorata in a Baltic archipelago in relation to environmental factors. Mar. Biol., 111, 237-246.

Valkama, J. \& Anttila-Huhtinen, M. 2000. Pohjaeläintutkimukset Kymijoella 1998 ja 1999 sekä Pyhtään, Kotkan ja Haminan merialueilla vuosina 1993-1999. Kymijoen vesiensuojeluyhdistys ry: julkaisu, 86, 1-22.

Varmo, R. 1994. Pohjaeläimistö Helsingin ja Espoon merialueilla vuonna 1991. Helsingin kaupungin ympäristökeskuksen julkaisuja, 10, 1-26.

\section{Olulised muutused Soome edelaosa rannikumere põhjaloomastiku liigilises koosseisus ja arvukuses - 1928. ja 2000. aasta võrdlus}

\section{Ari O. Laine, Kaisa Luodekari, Minna Poikonen ja Markku Viitasalo}

1928. aastal uuris Sven G. Segerstråle Tvärminne regiooni põhjakooslusi (Soome edelaosa rannikumeri). Lisaks traditsioonilisele esitusele ta ka fotografeeris uuritud kooslusi. Loomad olid asetatud mustale taustale ning nende paigutus vastas looduslikule asustustihedusele. Siinses uuringus kasutati sama metoodikat. Fotode võrdlus näitab, et loomakooslused on viimase sajandi jooksul oluliselt muutunud. Sügavamatel aladel on kirpvähi (Monoporeia affinis) kooslus asendunud balti lamekarbi (Macoma baltica) kooslusega. Madalamatel aladel on mitmekesine Corophium volutator' i-Macoma baltica-Chironomidae kooslus asendunud Macoma baltica ja Põhja-Ameerika tulnukliigi Marenzelleria viridis'e kooslustega. Lisaks on suurselgrootute asustustihedus oluliselt vähenenud. Muutuste põhjused on ebaselged, kuid suure tõenäosusega võib neid seostada eutrofeerumisnähtustega ning sellest tulenevate muutustega liikidevahelistes vastastikmõjudes. 